\title{
Factors affecting online coffee purchases in the Covid-19 pandemic era: consumer case study at Jotey Coffee Shop
}

\author{
Fatores que afetam as compras on-line de café na era pandêmica da Covid-19: estudo de caso do \\ consumidor na Jotey Coffee Shop
}

Factores que afectan las compras de café en línea en la era de la pandemia de Covid-19: estudio de caso del consumidor en la Cafetería Jotey

\author{
Muhammad Iqbal Karima ${ }^{1}$ \\ ORCID: https://orcid.org/0000-0002-0906-8090 \\ Mercu Buana University, Jakarta, Indonesia \\ E-mail: iqbalekarima@gmail.com \\ Dipa Mulia ${ }^{1}$ \\ ORCID: https://orcid.org/0000-0002-8039-5924 \\ Mercu Buana University, Jakarta, Indonesia \\ E-mail: dipa.mulia@mecubuana.ac.id
}

\begin{abstract}
Research in journal aim for analyze the factors that influence the purchase of coffee online in the era of the Covid 19 pandemic at the Jotey Coffee Shop. This research uses methodde quantitative. The population in this study are online buyers, especially Jotey coffee at the Jotey Coffee Shop, East Bekasi with a sample size of 240 consumers Kedai Jotey, where the sample uses the Hair method. Test the hypothesis proposed in this study done with tool test analysis regression and hypothesis partial and simultaneous by using software Smartpls 3.2.9. Results analysis show that: 1) Communication a positive and significant effect on online coffee purchasing decisions, 2) Process has a positive and significant effect on online coffee purchasing decisions, 3) Price has a negative and significant effect on online coffee purchasing decisions, 4) Product has a positive and significant effect on online purchasing decisions contemporary coffee, 5) Character has a positive and significant effect on online purchasing decisions for contemporary coffee, and 6) Risk does not have a positive and significant effect on online purchasing decisions for contemporary coffee at the Jotey Coffee Shop.
\end{abstract}

Keywords: Communication; Process, Price; Product; Character; Risk; Purchase decision.

\section{Resumo}

A pesquisa em periódico visa analisar os fatores que influenciam a compra de café online na era da pandemia Covid 19 no Jotey Coffee Shop. Esta pesquisa utiliza um método quantitativo. A população neste estudo são compradores online, especialmente café Jotey no Café Jotey, East Bekasi com um tamanho de amostra de 240 consumidores Kedai Jotey, onde a amostra usa o método Hair. Teste a hipótese proposta neste estudo feito com ferramenta teste de regressão de análise e hipótese parcial e simultânea por meio do software Smartpls 3.2.9. A análise dos resultados mostra que: 1) A comunicação tem um efeito positivo e significativo nas decisões de compra de café online, 2) $\mathrm{O}$ processo tem um efeito positivo e significativo nas decisões de compra de café online, 3) O preço tem um efeito negativo e significativo nas decisões de compra de café online, 4 ) O produto tem um efeito positivo e significativo nas decisões de compra online de café contemporâneo, 5) O caráter tem um efeito positivo e significativo nas decisões de compra online de café contemporâneo e 6) O risco não tem um efeito positivo e significativo nas decisões de compra online de café contemporâneo café no Café Jotey.

Palavras-chave: Comunicação; Processo, preço; Produtos; Personagem; Risco; Decisão de compra.

\section{Resumen}

La investigación en revista tiene como objetivo analizar los factores que influyen en la compra de café online en la era de la pandemia Covid 19 en el Jotey Coffee Shop. Esta investigación utiliza un método cuantitativo. La población de

\footnotetext{
${ }^{1}$ Master in Management, Mercu Buana University, Jakarta, Indonesia.
} 
este estudio son compradores en línea, especialmente café Jotey en Jotey Coffee Shop, East Bekasi con un tamaño de muestra de 240 consumidores Kedai Jotey, donde la muestra utiliza el método Hair. Probar la hipótesis propuesta en este estudio realizado con herramienta de análisis de prueba de regresión e hipótesis parcial y simultánea mediante el uso del software Smartpls 3.2.9. El análisis de resultados muestra que: 1) La comunicación tiene un efecto positivo y significativo en las decisiones de compra de café en línea, 2) El proceso tiene un efecto positivo y significativo en las decisiones de compra de café en línea, 3) El precio tiene un efecto negativo y significativo en las decisiones de compra de café en línea, 4 ) El producto tiene un efecto positivo y significativo en las decisiones de compra en línea del café contemporáneo, 5) El carácter tiene un efecto positivo y significativo en las decisiones de compra en línea para el café contemporáneo, y 6) El riesgo no tiene un efecto positivo y significativo en las decisiones de compra en línea para el café contemporáneo. café en la cafetería Jotey.

Palabras clave: Comunicación; Proceso, Precio; Producto; Personaje; Riesgo; Decisión de compra.

\section{Introduction}

The phenomenon of the Coronavirus Diseases (Covid 19) Pandemic has had an impact on people's activities today. The implementation of Large-Scale Social Restrictions (PSBB) has reduced some market activities, resulting in a decline in the community's economy. This impact also affects the social behavior of coffee fans.

We can see this in their behavior before the pandemic, the number of cafes, coffee shops, shops and stalls filled with coffee fans with various activities or just hanging out and even having discussions. Changes in consumer behavior in the use of e-wallet as a result of the outbreak of COVID-19. Various policies or appeals implemented by the government, be it PSBB, stay at home, work from home, study from home, as well as reducing the use of cash have clearly changed consumer behavior.

To be able to survive in the midst of this pandemic, there are three business strategies that are carried out. First, focus on online delivery. Because, even though there is currently a pandemic, it doesn't mean people don't drink coffee, only the way they buy it has changed. Where customers buy everything online. An unusual phenomenon, physically, of customers drinking coffee on the spot decreased, while online sales increased. Therefore, digital marketing, social media, and online delivery are needed. Based on this, this has happened in the retail industry, where before the Covid-19 outbreak, physical sales decreased, while online sales increased. This phenomenon occurs because the digital world and all the conveniences provided are slowly suppressing the existence of their stores (Figure 1).

Figure 1. Comparison of income of types of goods during 2018-2019.

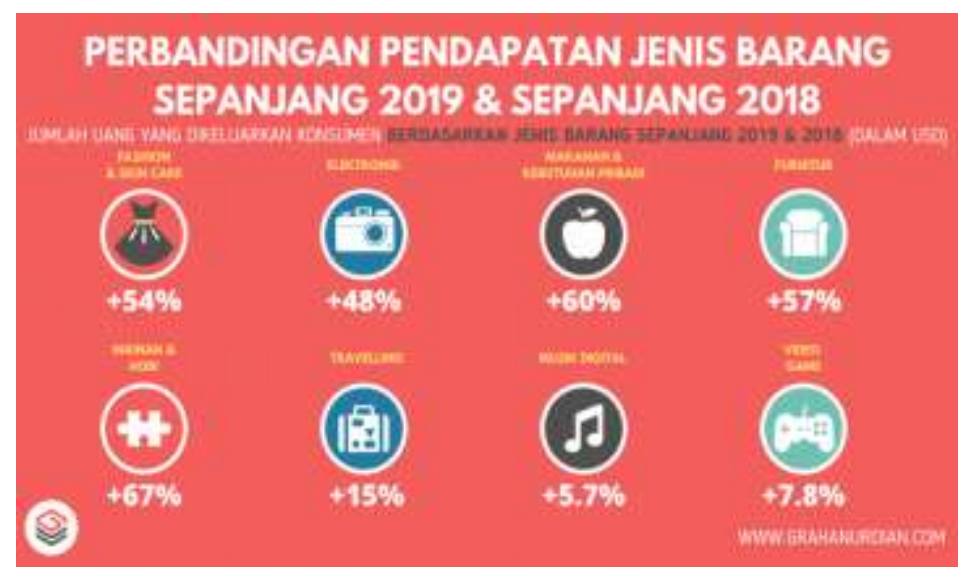

Source: Authors.

The figure shows a drastic increase in online shopping behavior from Indonesian e-commerce throughout 2018 and throughout 2019. This shows a shift in habits from regular store shopping to shopping from online stores. This is helped by 
many influencing factors such as smartphone, data/internet plan, access, etc. increasingly affordable.

Items such as Food and Personal Necessities, Furniture, and Toys or Hobbies are increasing rapidly along with the ease of delivery of goods. Meanwhile, Fashion and Electronics are increasing as it becomes safer to shop online in Indonesian e-commerce. This also applies to the Jotey Coffee Shop, both before and during Covid 19. Where the concept of Jotey Coffee is selling coffee online, fresh by order and opening the refrigerator stock drinks. Jotey coffee is served in the form of a cup or bottle, or for those who want to come directly to the place it can be served in a glass. Jotey's coffee shop is not a cafe, but a house that is joined together with the house of the leader of Record Indonesia in one place.

Jotey coffee is a drink made from Arabica coffee, fresh milk, palm sugar and there is also a chocolate menu. Without using preservatives, artificial colors and synthetic sweeteners, this coffee is ready to enliven the beverage market, coffee and chocolate in particular. That kind of coffee is also ready for any events, such as weddings, celebrations and others. Jotey coffee uses HALAL ingredients. Based on the phenomenon that occurred, it showed an increase in online income at the Jotey Coffee Shop, while offline income at the Jotey Coffee Shop decreased for the period from July 2019 to August 2020 (Figure 2):

Figure 2. Online Income at Jotey Coffee Shop for the Period of July 2019-August 2020.

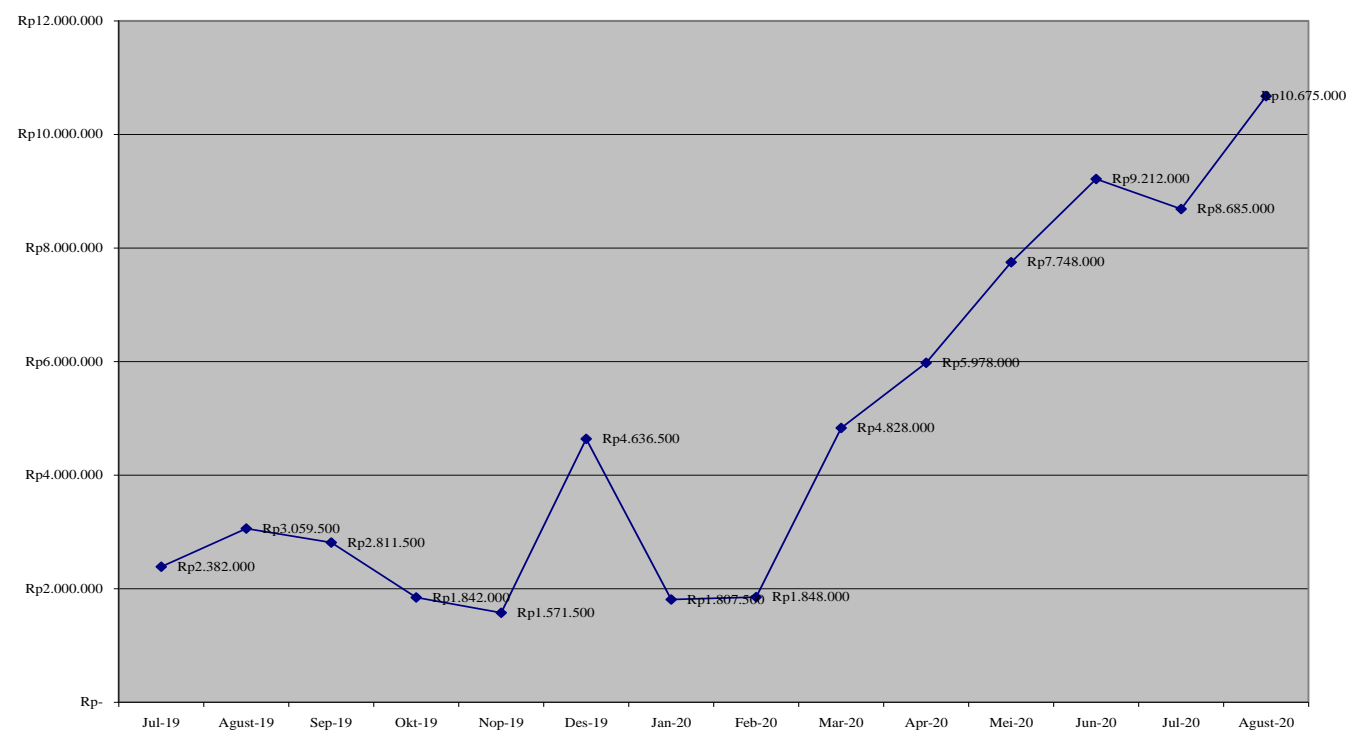

Source: Authors.

It can be seen in the picture where the increase and decrease in income from online coffee sales at the Jotey Coffee Shop in July 2019 as much as Rp. 2,382,000 to Rp. 10,675,000 in August 2020.

In January 2020, it decreased by Rp. 2,829,000 (61.02\% ) from December 2019 of Rp. 4,636,500, while in March 2020recorded a significant increase in sales using online methods during Covid-19 which experienced an increase of more than 50 percent for online sales. Given the large number of social media users today, social media marketing is one of the most effective strategies to promote Jotey Coffee Shop.

It can also be seen in the picture showing that on-site (physical) or offline purchases have increased during the month of July 2019 this is due to the promotions carried out by the Jotey Coffee Shop in the form of buy one get one until December 2019, but from January 2020 continuously until August 2020 experienced a decline in sales due to the continuous extension of the PSBB until now (Figure 3). 
Figure 3. Offline Income at Jotey Coffee Shop for the Period of July 2019-August 2020.

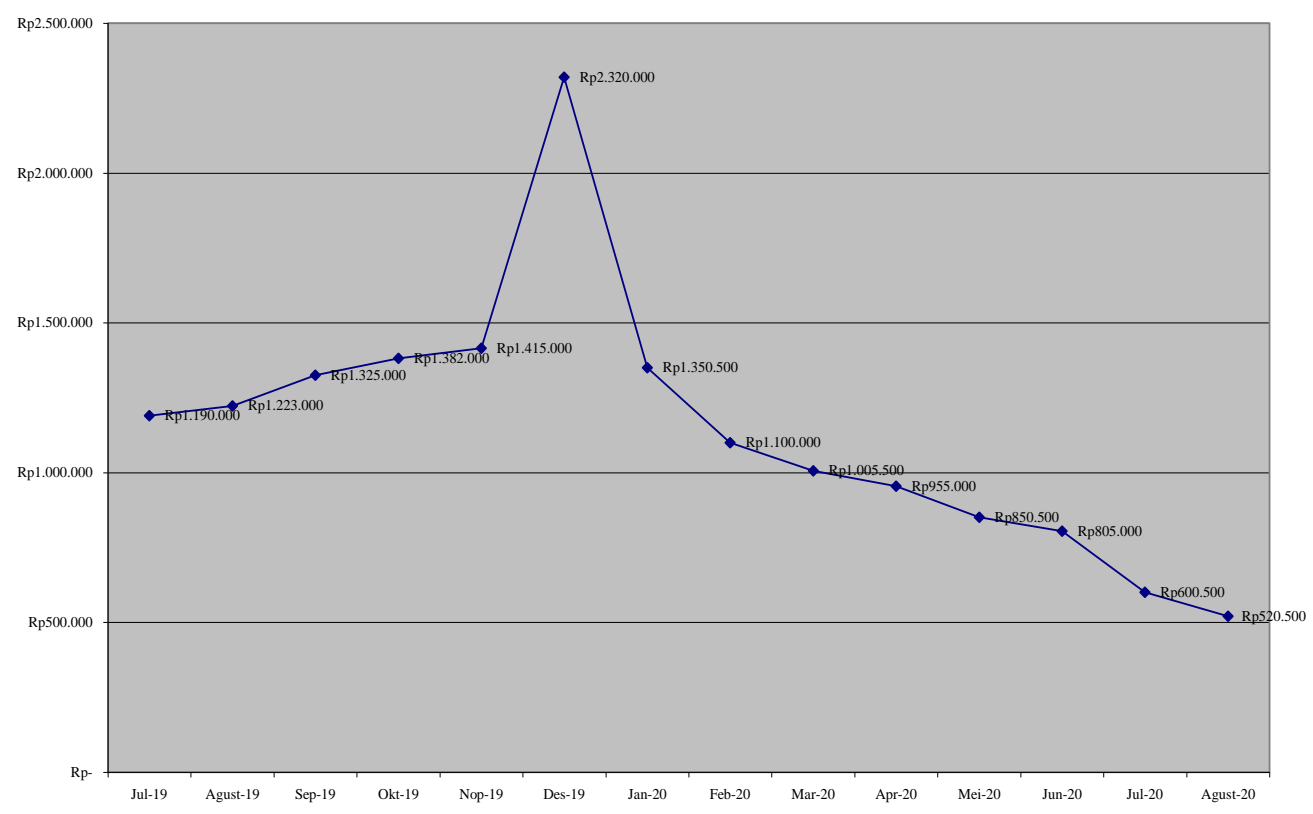

Source: Authors.

When compared to Figures 3 and 4, it shows a significant difference where the composition of online sales is better than offline sales at the Jotey Coffee Shop for the period of July 2019-August 2020.

Associated with online purchasing decisions, where research on consumer behavior on purchasing decisions has been widely carried out. Many factors influence consumer behavior in purchasing decisions.

In making a purchase decision, a consumer is influenced by internal factors and external factors. In addition, the number of online shopping sites is more noticed by consumers, there are certain sites that are deceptive, unclear, and so on.

From this study, researchers took several factors from previous studies to be re-examined, therefore researchers conducted a pre-survey of 30 respondents to find out the reasons they made online purchasing decisions by choosing five main factors (attached), the following data were obtained (Figure 4): 
Figure 4. Pre-Survey Results Preliminary.

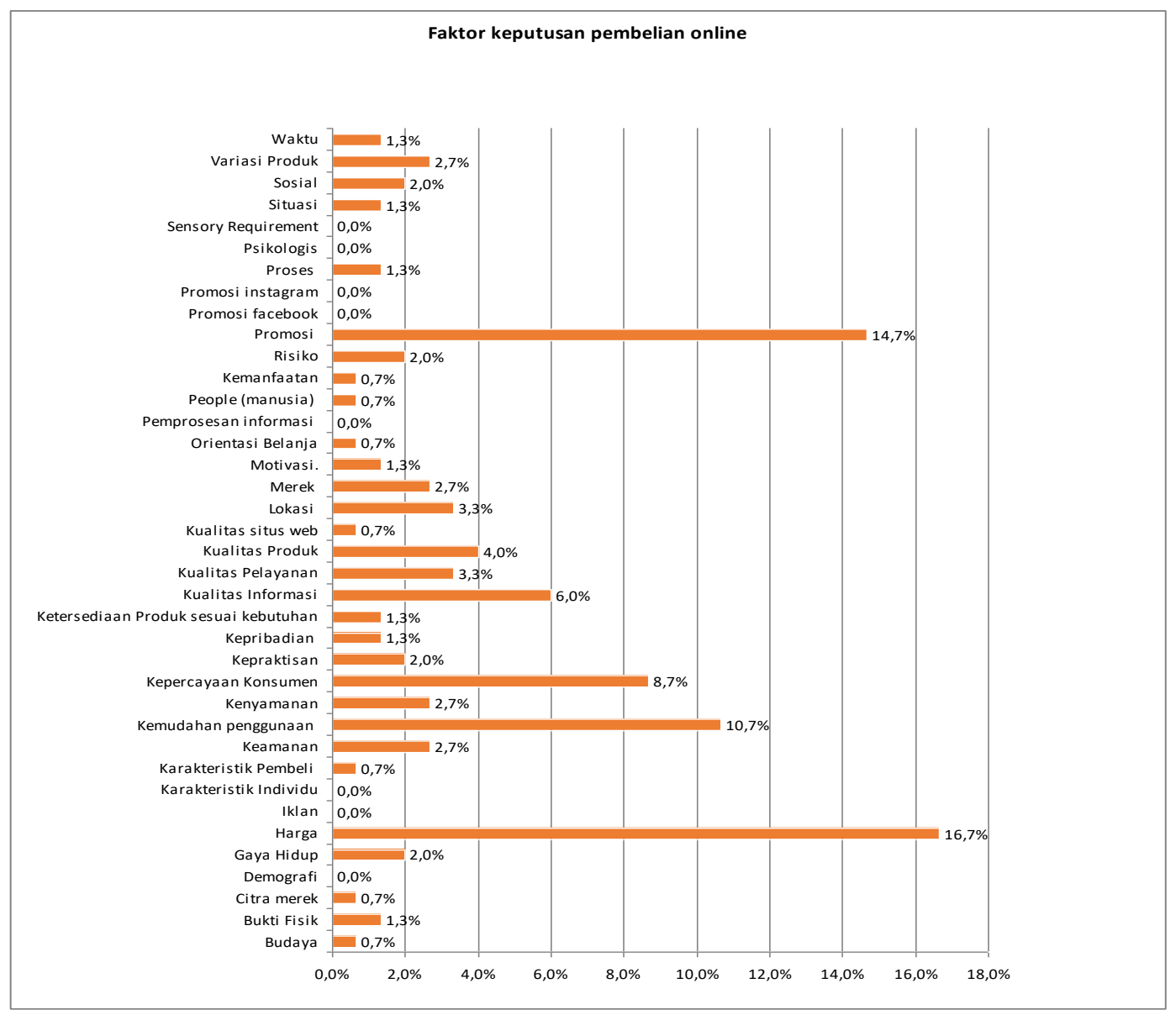

Source: Pre-survey data (2020).

From the results of the pre-survey above, it was found that there were several variables that became the main factors of 30 respondents to make purchases online with the following factors: harga, promotions carried out online on social media, ease of use of online facilities, consumer trust, and the quality of information obtained by consumers, product quality, online service quality, location, product variety, safety, comfort, lifestyle, practicality and social factors.

Where the results of the pre-survey of the price variable were $16.7 \%$; online promotion variable as much as $14.7 \%$; convenience of $10.7 \%$; consumer confidence as much as $8.7 \%$; information quality by $6 \%$; product quality by $4 \%$; online service quality by $3.3 \%$; location by $3.3 \%$; product variety by $2.7 \%$; security by $2.7 \%$; comfort by $2.7 \%$; lifestyle by $2 \%$; practicality by $2 \%$; and social factors by $2 \%$ so that the total becomes $81.3 \%$ while the remaining $18.7 \%$ is due to other factors. To facilitate research in finding variables, grouping analysis is carried out to obtain new variables, as follows (Figure 5): 
Figure 5. Grouping analysis.

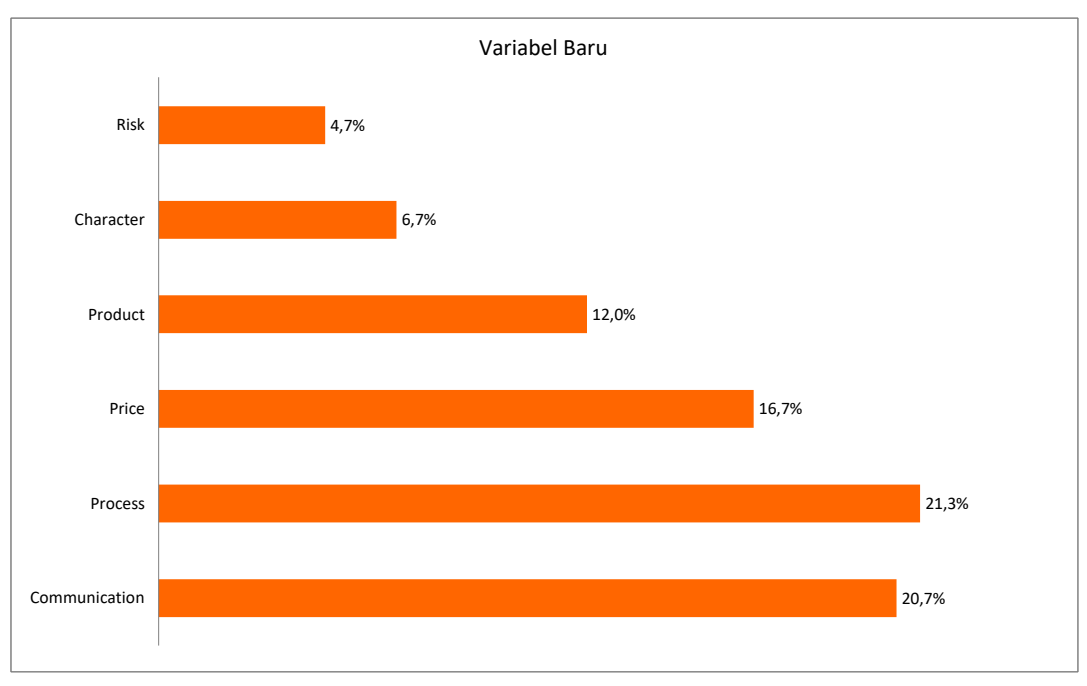

Source: Pre-survey data (2020).

\section{New Variable Group Analysis Results}

Based on group analysis, it shows that there are six new variables that influence online purchasing decisions, namely communication, process, price, product, characte, and risk with each percentage of $20 \%, 21.3 \%, 16.7 \% 12 \% 6.7 \%$ and $4.7 \%$.

Research gap-The problem in this study is the Corona Pandemic which causes a decrease in transactions in general but does not occur in online transactions for coffee sales, especially at the Jotey Coffee Shop, so it is necessary to do research related to factors that cause an increase in online transactions in coffee sales. This is in accordance with data on the decline in physical transactions (offline) in the retail business sector, which relies more on physical stores, which is now increasingly under pressure due to changes in shopping trends that shift toworld on line. People are increasingly avoiding public places and offline retail stores, so online sales for some sectors are increasing. Reporting from neilpatel.com, conversions for the food, health and pharmaceutical sectors increased significantly. The food sector experienced an increase of 55\%, health 19\%, and pharmaceuticals $11 \%$. In the United States alone, online sales are predicted to increase by up to $12 \%$ of the total spending in 2020.

In addition, it is also supported by the results of research conducted by (Kusno, Fadli, Karyani, 2019), (Mu LIANI, 2016), (Asrizal Efendy Nasution, 2019) and (Lestari, Winarno, 2017); (Ni Kadek Devi Aprillia Agustini, 2017), (Asrizal Efendy Nasution, 2019), (Wardoyo \& Andini, 2017); (Wahono, 2020), (Wardoyo \& Andini, 2017), (Gunawan, Linawati, Pranandito, 2019), and (Mu LIANI, 2016); and (Evelyn Wijaya, 2019), (Ni Kadek Devi Aprillia Agustini, 2017) related to online purchasing decisions.

Looking at the existing phenomena and research gaps in research, the results of previous studies, and preliminary surveys, this study intends to analyze Factors Affecting Online Coffee Purchases in the Covid-19 Pandemic Era (Consumer Case Study at Jotey Coffee Shop).

\section{Theory Study}

\section{Grand Theory (TAM Theory)}

Technology Acceptance Modelhereinafter referred to as TAM is one of the adaptation theories of TRA (Theory of Reasoned Action) which was previously introduced by Ajzen and Fishbein in 1980 and proposed by Davis in 1989 (Jogiyanto, 
2017). TRA is a theory that explains a behavior carried out because individuals have the will or intention to carry out related activities to be carried out on their own volition. TAM describes a causal relationship between a belief (the benefits of an information system and its ease of use) and the behavior, needs and users of an information system. TAM aims to explain and estimate user acceptance of an information system.

\section{Middle Theory (Planned Behavior)}

Theory of Planned Behavior (TPB) explains that consumer behavior is shaped by attitudes, subjective norms, and perceived behavioral control (PBC) that form intentions. Intentions then influence how a person behaves. This theory forms the basis of the current study that analyzes the influence of intention on online buying behavior. This model was developed by Icek Ajzen to enhance the predictive power of Theory of Reasoned Action (TRA), by adding the PBC variable.

\section{Middle Theory (Theory of Reasoned Action)}

Theory of Reasoned Action (TRA) describes behavior that changes based on the results of behavioral intentions, and behavioral intentions are influenced by social norms and individual attitudes towards behavior (Eagle, Dahl, Hill, Bird, Spotswood, \& Tapp, 2013: 123). Subjective norms describe individual beliefs about normal and acceptable behavior in society, while individual attitudes towards behavior are based on individual beliefs about that behavior.

\section{Consumer Decision Model}

The topic of this research is consumer behavior in the purchasing decision-making process. Purchasing begins with the introduction of needs, then followed by information search, evaluation, purchase, then post-purchase evaluation. This study analyzes the decision-making process from the information search stage to the purchase made in the context of e-commerce. Based on this scope, the theory that forms the basis of this study is the theory of consumer purchasing decisions.

\section{Online Purchase Decision}

(Turban, Efraim, 2004), (Katawetawaraks and Wang, 2011) explain that online shopping is an activity of purchasing products (either goods or services) through the internet. Online shopping activities include Business to Business (B2B) and Business to Consumers (B2C) activities. While in the research, online shopping activities are associated with B2C because the intended purchasing activities are buying activities used by consumers themselves, not resale. Online shopping activities here are retail transactions with individual buyers, so online shopping here is a buying decision made by individuals online. One of the benefits of online shopping is that prospective buyers can see in advance (the product) they are going to buy via the web offered by the seller.

\section{Communication (Communication)}

Communication is a process where two or more people form or exchange information with each other which in turn will arrive at a deep mutual understanding. Communication is a social process that occurs between at least two people in which one person sends a certain number of symbols to another person (Kennedy, 2006).

\section{Process (Process)}

According to (Lupiyoadi, 2014) the process is a combination of all activities, generally consisting of procedures, work schedules, mechanisms, activities, and routine matters, where services are produced and delivered to consumers. Meanwhile, 
according to (Irawan, 2012) processes are all actual procedures, mechanisms and flow of activities by which services are delivered which is a service delivery system or operation.

\section{Price (Price)}

(Abdullah, Thamrin., 2012) price is the sum of the value exchanged by consumers or the benefits for owning or using the product/service. Meanwhile, (Istijanto, 2009) states that price is the money paid by consumers to obtain the desired service by comparing the costs and benefits. obtained (The Consumer's costs and benefits)". According to (Philip Kotler, 2010), in the price variable there are several elements of the main price activity which include price lists, discounts, rebates, and payment periods.

\section{Products (Product)}

According to (Irawan, Deny, dan Japarianto, 2013), the product is an object that is tangible, as well as intangible that people can buy. Companies that do not procure or are unable to create new products will face risks such as decreased sales volume, due to the emergence of more creative competitors, changes in consumer tastes.

\section{Characters (Character)}

(Samani, 2011) argues that character can be interpreted as a basic value that builds a person's personality, formed both due to the influence of heredity and environmental influences, which distinguishes him from others, and is manifested in his attitudes and behavior in everyday life.

\section{Risk (Risk)}

Risk is a precursor factor that gains trust (Gefen, D., Karahanna, E. and Straub, D.W., 2003). In trading on the internet, the risk is considered to be higher than physical trading because of the limited physical contact of consumers with products, so that consumers cannot monitor product performance before making a purchase. According to (Ferrinadewi, 2008), perceived risk is a negative consumer perception of a number of activities based on negative results and allows the results to be real. This is a problem that is always faced by consumers and creates an uncertain condition, for example when consumers decide to buy a new product.

\section{Framework}

Authors develop framework in Figure 6 as follows: 
Figure 6. Framework showing variables.

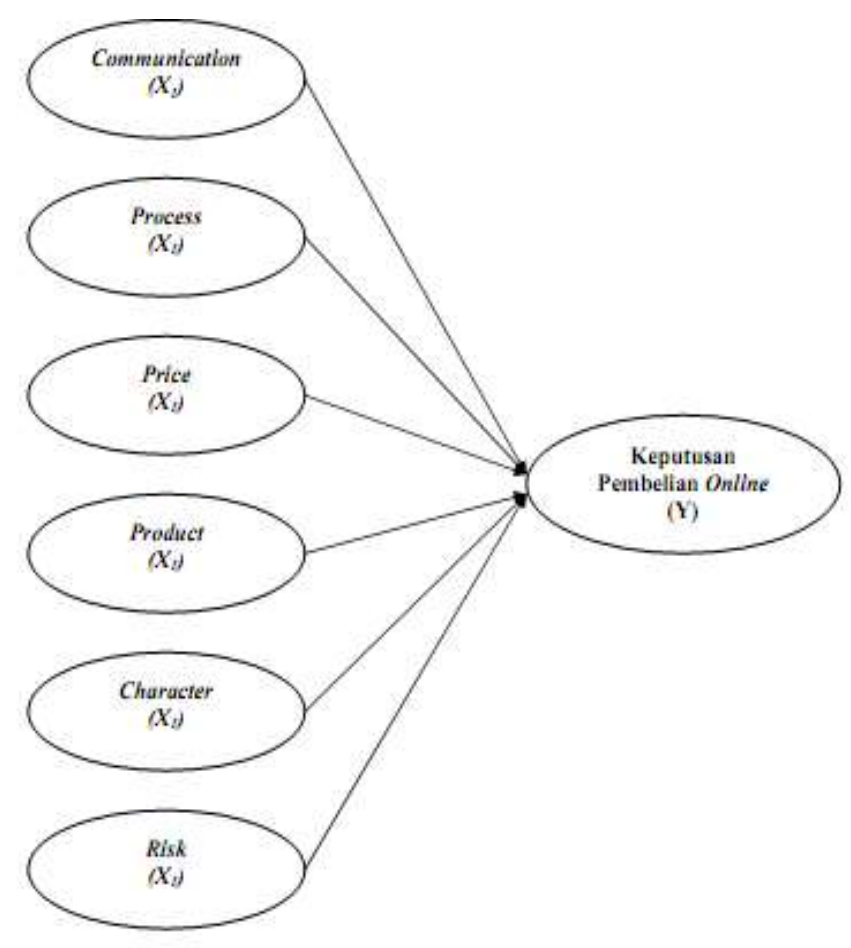

Source: Authors.

\section{Hypothesis Development}

\section{The influence of communication on online purchase decision}

Communication is the process of disseminating information about the company and what it has to offer (offering) to the market (Sulaksana, 2007). In marketing communication, a marketing strategy is needed, which is a fundamental way to achieve company goals. In communication, social media is often used, especially Instagram, Facebook, YouTube and others. This has gradually made internet-based marketing the preferred mode of communication, especially in increasing online purchasing decisions, which have an impact on sales. The communication strategy in marketing 4.0 has an influence on purchase decisions (Muhammad Darwin, 2020). This is also supported by the positive relationship between digital communication on customer buying decisions, in addition to the significant influence between e-wom communication on purchase decisions (Hardjono et al., 2020).

H1 : Communication have influence on the decision to purchase contemporary coffee at the Jotey Coffee Shop

\section{Process effect on online purchasing decisions}

Process is a method or mechanism used by employees to attract consumers to buy goods and services offered. The faster and better the process provided, for example in the payment process at the cashier, and when a claim occurs, such as if an item is damaged, it will increase consumer interest in buying. This is supported by the relationship between the process and purchasing decisions (Edward Panjaitan, Sukaria Sinulingga, 2019).

H2 : Process have influence on the decision to purchase contemporary coffee at the Jotey Coffee Shop

\section{Price effect on purchasing decisions}

Price is one of the elements of the marketing mix, according to the nature of the marketing mix, price is a variable that 
can be controlled by the company. In addition, the price also determines whether or not a product is accepted by consumers. Companies need to monitor the prices set by competitors so that the prices set by the company are not too high or vice versa, so that the prices offered can lead to consumer desires to make purchases. Many studies have been conducted to support the statement that price has a positive influence on online purchasing decisions (Baruna Hadi Brata, Shilvana Husani, 2020; Edward Panjaitan, Sukaria Sinulingga, 2019; Erna S.Imaningsih dan Saiful Rohman, 2018; Parmana, Idqan Fahmi, 2019).

H3 : Price have influence on online coffee purchasing decisions at the Jotey Coffee Shop.

\section{Product effect on online purchasing decisions}

Consumers buy not just a collection of physical attributes, but in the end they pay something to satisfy a want. If someone needs a product, they will first imagine the benefits of the product, then consider other factors other than the benefits of the product. These factors make consumers make the decision to buy or not. Many studies have been carried out to support the statement that the product has a positive influence on purchasing decisions (Baruna Hadi Brata, Shilvana Husani, 2020; Diana-Rose, 2016; Edward Panjaitan, Sukaria Sinulingga, 2019; Erna S.Imaningsih dan Saiful Rohman, 2018; Parmana, Idqan Fahmi, 2019).

H4 : Product have influence on the decision to purchase contemporary coffee at the Jotey Coffee Shop

\section{Influence of character on online purchasing decisions}

Consumer characteristics are factors that are unique to a person. Various factors of consumer characteristics can influence purchasing decision factors (Sangadji, E.M., 2013). Consumer characteristics influence purchasing decisions, consumer characteristics factors include age and stage in the buyer cycle, occupation and economic circumstances, consumer characteristics and self-concept, as well as lifestyle and values. Because many of these characteristics have a very direct impact on consumer behavior (Kotler, P., \& Keller, 2016). Product choice is strongly influenced by economic circumstances, disposable income, savings and assets, debt, borrowing power and attitudes towards spending and saving. Consumer decisions are also influenced by core values, belief systems that underlie attitudes and behavior (Kotler, P., \& Keller, 2016). According to research, there is a significant positive effect between consumer characteristics factors on purchasing decisions (Lakshmi. S, 2016; Sheikh Qazzafi, 2019; Widya Rambi, 2015).

H5 : Character have influence on the decision to purchase contemporary coffee at the Jotey Coffee Shop

\section{Effect of risk on online purchasing decisions}

Through good communication, consumers will feel comfortable and reduce the perception of consumer risk in transactions, and this will ultimately be able to influence consumers in determining purchasing decisions through online media. Associated with online fraud, online shop owners must pay attention to service quality in terms of processes to minimize the level of customer perceived risk. This is because the perception of risk contains the uncertainty of a situation. In online trading transactions, there are at least three kinds of risks that may occur, namely product risk, transaction risk, and psychological risk. Product risk refers to the uncertainty that the purchased product will perform as expected. while transaction risk is the uncertainty that will result in harming consumers in the transaction process, and psychological risk is the fears that may occur during the purchase or after the purchase (Sukma, 2011). Many studies have been carried out to support the statement that risk has a significant influence on purchasing decisions. (Aishah Arshad, Maira Zafar, Iffat Fatima, 2015; Ankita Popli, 2015; Meciejewski G, 2011; Ryan Kusumah, 2015).

H6 : risk have influence on the decision to purchase contemporary coffee at the Jotey Coffee Shop 


\section{Research Methods}

In general, the research method is defined as a scientific way to obtain data with a specific purpose and use. Which is used for efforts to find, develop, know the truth of a knowledge that is carried out by scientific methods (Sugiyono, 2014). This research belongs to the quantitative category, which is based on a positivism approach. In this case, the researcher wants to describe the factors that influence online purchasing decisions. The general population in this study are all current coffee buyers at the Jotey Coffee Shop, East Bekasi, both offline and online buyers, while the target population in this study are online buyers, especially Jotey coffee at the Jotey Coffee Shop East Bekasi.

Respondents who were sampled in this study were online shoppers at the Jotey Coffee Shop with the following criteria:

1. Age more than 15 years. With an adult age, respondents are expected to be able to make an objective assessment of the statements in the questionnaire related to the research variables.

2. Consumers who have been to Kedai Jotey and have shopped online

3. Consumers are generally located in the Bekasi area, especially East Bekasi

4. Respondents selected by consumers who are buying Jotey Coffee online at least 2 times.

Determination of the minimum number of samples for analysis according to Hair et al (2010) are:

(Number of indicators) $\mathrm{x}$ (5 to 10 times)

Based on these guidelines, the maximum sample size for this study is:

Maximum sample $=(24) \times 10=240$ respondents

Based on the above formula, the maximum number of samples in This research is 240 consumer respondents Jote's shop.

Techniques in data analysis used by using IBM SPSS Version 26 and SmartPLS. SmartPLS software is used to simplify data processing, so that the results are faster and more precise.

1. Measurement Model or Outer Model

2. Structural Model or Inner Model

3. Hypothesis Testing (Estimate For Path Coefficients)

\section{Results and Discussion}

In carrying out a series of statistical analyzes the data will be divided into several parts consisting of analyzes as described below: 
Figure 7. Evaluation of Measurement (Outer) Model.

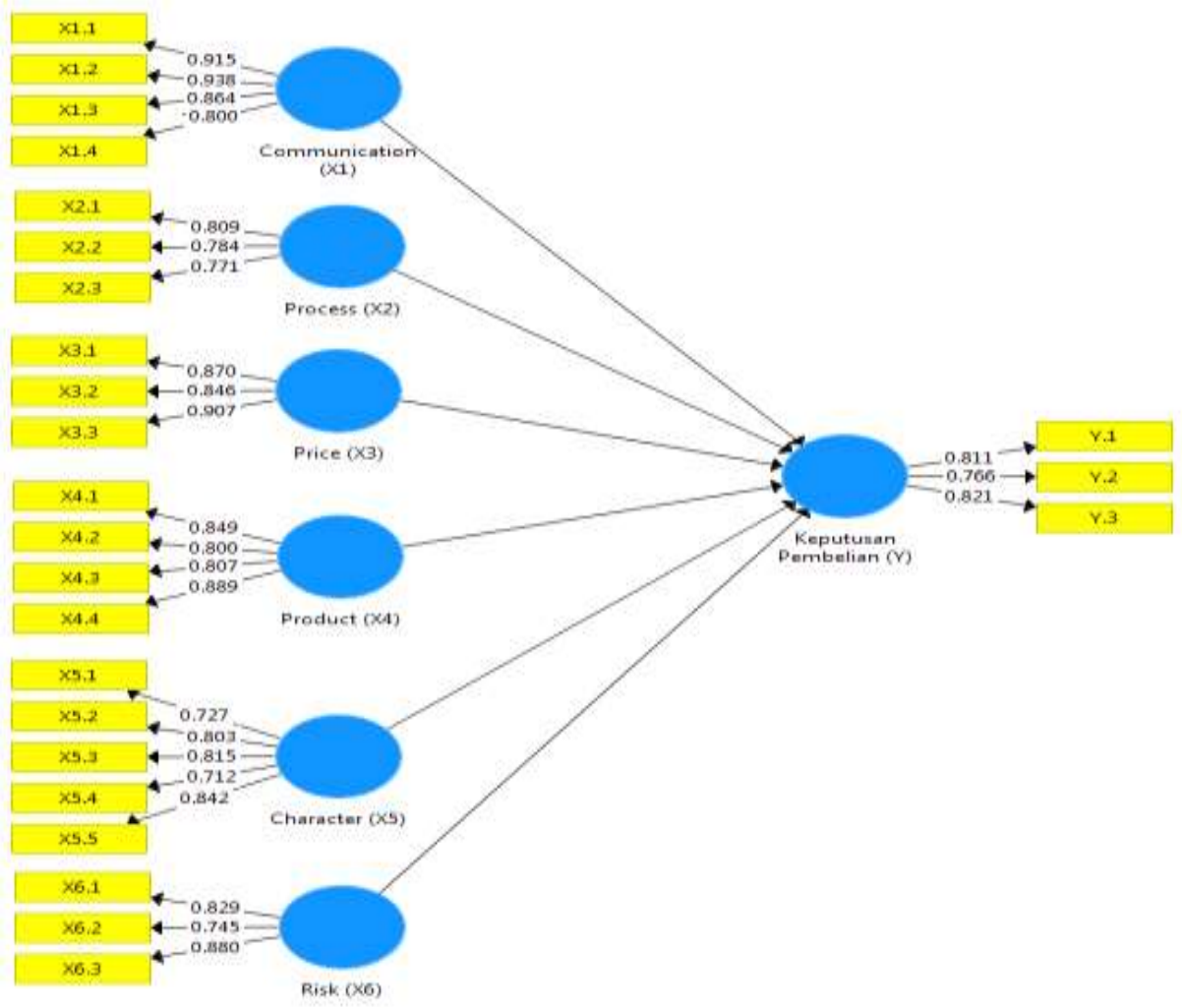

Source: Authors.

\section{Validity test}

\section{Convergent Validity}

Convergent Validity From the measurement model, it can be seen from the correlation between the item/indicator scores and the construct score (Loading Factor) with the loading factor criteria for each indicator 0.70.

Based on the results of Phase I data processing, the values of the indicators above have met the criteria, which are more than 0.70. Based on the test results of the measurement model shown in the figure and table, the constructs of the research variables all indicators have a loading factor above 0.7 and an AVE of 0.5. Based on the results of the loading factor above, it can be concluded that the construct has good convergent validity.

\section{Discriminant Validity}

Based on the cross loading value of each variable has a value above 0.70 so that the results have no problem with Discriminant Validity.

\section{Reliability Test}

Based on the results of Composite Reliability and Cronbach's Alpha all of them have values above 0.6 and 0.7 so that the values on all instruments can be said to be reliable.

\section{Structural Model Testing (Inner Model)}

\section{R-Square}

Based on the obtained R-Square value of 0.971 which can be interpreted that the variability of the purchase decision 
construct which can be explained by the variability of the construct of communication (communication), process (process), price (price), product (product), character (character) and risk (risk) of $97.1 \%$ while $2.9 \%$ is explained by other variables outside the study. Based on this, the results of the calculation of $\mathrm{R} 2$ indicate that the value is close to strong.

In addition, it can be seen that the R-Square adjusted value for the construct of consumer satisfaction is 0.943 . It means that the model has a good level of goodness-fit model. This also means that the variability of purchasing decisions can be explained by six variables in the model, namely communication (communication), process (process), price (price), product (product), character (character) and risk (risk) of $94.3 \%$. The reason for using the R-Square adjusted is because the value does not always increase when additional variables are added (Ghozali, 2013).

\section{Evaluation Goodness of Fit Model (GoF)}

The results of the goodness of fit test of the PLS model show that the NFI value of 0.791 means FIT. Thus from these results it can be concluded that the model in this study has a high goodness of fit and is suitable to be used to test the research hypothesis. Table 1 shows boostrapping results.

Table 1. Bootstrapping Results.

\begin{tabular}{|l|l|l|l|l|}
\hline Direct Effect & $\begin{array}{l}\text { Original } \\
\text { Sample (O) }\end{array}$ & $\begin{array}{l}\text { T Statistics } \\
(|\mathbf{O} / \mathbf{S T D E V}|)\end{array}$ & P Values & Sig. \\
\hline $\begin{array}{l}\text { Communication (X1) -> } \\
\text { Purchase Decision (Y) }\end{array}$ & 0.153 & 4,316 & 0.000 & $\begin{array}{l}\text { Have influence } \\
\text { Positive } \\
\text { and Significant }\end{array}$ \\
\hline $\begin{array}{l}\text { Process (X2) -> } \\
\text { Purchase Decision (Y) }\end{array}$ & 0.130 & 2,796 & 0.005 & $\begin{array}{l}\text { Have influence } \\
\text { Positive } \\
\text { and Significant }\end{array}$ \\
\hline $\begin{array}{l}\text { Price (X3) -> } \\
\text { Purchase Decision (Y) }\end{array}$ & -0.136 & 2,256 & 0.024 & $\begin{array}{l}\text { Have influence } \\
\text { Negative } \\
\text { and Significant }\end{array}$ \\
\hline $\begin{array}{l}\text { Product (X4) -> } \\
\text { Purchase Decision (Y) }\end{array}$ & 0.199 & 2,421 & 0.016 & $\begin{array}{l}\text { Have influence } \\
\text { Positive } \\
\text { and Significant }\end{array}$ \\
\hline $\begin{array}{l}\text { Characters (X5) -> } \\
\text { Purchase Decision (Y) }\end{array}$ & 0.755 & 12,545 & 0.000 & $\begin{array}{l}\text { Have influence } \\
\text { Positive } \\
\text { and Significant }\end{array}$ \\
\hline $\begin{array}{l}\text { Risk (X6) -> } \\
\text { Purchase Decision (Y) }\end{array}$ & -0.097 & 1,794 & 0.073 & $\begin{array}{l}\text { Do not have } \\
\text { positive effect } \\
\text { and Not Significant }\end{array}$ \\
\hline
\end{tabular}

Source: Authors.

Based on the results, the effect of communication on online purchasing decisions is positive with a parameter coefficient of 0.153. Furthermore, based on T-Statistics H1 of 4.316 is greater than the real level or $4.316>1.96$ (ttable value with $n=240$ and $\square=0.05$ ) and the P-values of 0.000 are smaller than the real level or $0.000<0.05$, this indicates that the influence of communication on online coffee purchasing decisions at the Jotey Coffee Shop is significant, it can be concluded that $\mathrm{H} 01$ is rejected and $\mathrm{Ha} 1$ is accepted.

Based on the results, the effect of the process on online purchasing decisions is positive with a parameter coefficient of 0.130. Furthermore, based on T-Statistics H2, 2.796 is greater than the real level or 2.796>1.96 and the P-values are 0.005 smaller than the real level or $0.005<0.05$. Jotey Coffee Shop is significant, it can be concluded that $\mathrm{H} 02$ is rejected and $\mathrm{Ha} 2$ is accepted.

Based on the results, the effect of price on online purchasing decisions is negative with a parameter coefficient of - 
0.136. Furthermore, based on the T-Statistics H3 of 2.256 greater than the real level or $2.256>1.96$ and the P-values of 0.024 smaller than the real level or $0.024<0.05$ this indicates that the influence of price on online coffee purchasing decisions in Jotey Coffee Shop is significant, it can be concluded that H03 is rejected and Ha3 is accepted.

Based on the results, the effect of the product on online purchasing decisions is positive with a parameter coefficient of 0.199. Furthermore, based on T-Statistics H4 of 2.421, which is greater than the real level or $2.421>1.96$ and the P-values of 0.016 are smaller than the real level or $0.016<0.05$, this indicates that the influence of the product on online coffee purchasing decisions in Jotey Coffee Shop is significant, it can be concluded that H04 is rejected and Ha4 is accepted.

Based on the results, it shows that the influence of character on online purchasing decisions is positive with a parameter coefficient of 0.755. Furthermore, based on T-Statistics H5 of 12,545, which is greater than the real level or 4,316 > 1.96 and the P-values of 0.000 are smaller than the real level or $0.000<0.05$, this indicates that the influence of character on online purchasing decisions of contemporary coffee in Jotey Coffee Shop is significant, it can be concluded that H05 is rejected and Ha5 is accepted.

Based on the results, the effect of risk on online purchasing decisions is negative with a parameter coefficient of 0.097. Furthermore, based on T-Statistics H6, 1.794 is smaller than the real level or $1.794<1.96$ and the P-values are 0.073 greater than the real level or $0.073>0.05$. Jotey Coffee Shop is not significant, it can be concluded that H06 is accepted and Ha6 is rejected.

\section{Discussion}

\section{The influence of communication on online purchasing decisions}

There is a positive and significant influence on communication on the decision to buy modern coffee online at Kedai Kopi Jotey, the first hypothesis is tested. This means that the more communication provided by the Jotey Coffee Shop, the more current online coffee purchasing decisions will also increase. The marketing communication carried out by the Jote Coffee shop uses a marketing communication mix that combines various promotional elements such as personal selling, publicity, advertising, sales promotion, public relations, direct marketing, and also uses word-of-mouth communication by voicing the same thing, namely promoting the coffee shop. Jotey with the aim of preparing the needs of contemporary coffee drinkers and connoisseurs.

\section{The influence of process on online purchasing decisions}

There is a positive and significant influence process on the decision to purchase contemporary coffee at Kedai Kopi Jotey, the second hypothesis is tested. This means that as the process provided by the Jotey Coffee Shop increases, the current online coffee purchasing decisions will also increase. The results of this study support previous research that has been done. Process is how much computer technology is felt to be relatively easy to understand and use. This process factor is related to how operationally transacting online. Process is the most important thing that must be considered by online providers or sellers. This process can be of various levels, depending on the user or the buyer himself, but of course basically there is a standard process that is the same level for all users.

\section{The effect of price on online purchasing decisions}

There is a negative and significant effect on price On the decision to purchase contemporary coffee at Kedai Kopi Jotey, the third hypothesis is tested. This means that the lower the price given by the Jotey Coffee Shop, the more recent online 
coffee purchasing decisions will also increase. The results of this study support previous research that has been done. The current coffee prices offered by the Jotey Coffee Shop are included in the cheap category in encouraging consumer behavior in making purchasing decisions. However, the comparison of current coffee prices at the Jotey Coffee Shop is the same as other coffee shops according to the perception of most consumers. This is because the majority of respondents considered that the price offered by the coffee shop had a price range similar to the price offered by the Jotey Coffee Shop.

\section{The influence of the product on online purchasing decisions}

There is a positive and significant influence product On the decision to buy modern coffee online at Kedai Kopi Jotey, the fourth hypothesis is tested. This means that the more products provided by the Jotey Coffee Shop, the online purchasing decisions for contemporary coffee will also increase. The contemporary coffee products offered by the Jotey Coffee Shop are included in the satisfactory category, but the taste of the non-coffee drinks offered The Jotey Coffee Shop is quite suitable for the tastes of most consumers. This is because the majority of respondents considered that the taste of non-coffee drinks at the Jotey Coffee Shop tended to be not as delicious as those offered elsewhere. The products offered have a positive influence on consumer purchasing decisions at the Jotey Coffee Shop.

\section{The influence of character on online purchasing decisions}

There is a positive and significant influence character On the decision to purchase contemporary coffee at Kedai Kopi Jotey, the fifth hypothesis is tested. This means that the higher the character given by the Jotey Coffee Shop, the more recent online coffee purchasing decisions will also increase. The results of this study support previous research that has been done. Consumers admit that shopping for kekenian coffee at online retail suits them. The suitability in question is the compatibility between the values held by these consumers with the buying and selling process or with the value brought by the online retailer itself.

\section{The influence of risk on online purchasing decisions}

There is no positive and significant risk Regarding the current online coffee purchase decision at Kedai Kopi Jotey, the sixth hypothesis is not tested. This means that the risk that the Jotey Coffee Shop has does not affect the current online coffee purchase decision. The perceived risk of consumers is a barrier for consumers who are considering making a darling purchase. Consumers do not pay attention to risk in online transactions, and the absence of risk does not affect the decision to make a purchase. Consumers are influenced by their perceived risk, regardless of whether or not the risk actually exists. Risks that do not exist in consumer perceptions will not affect consumer behavior Evaluation.

\section{Conclusion and Suggestions}

\section{Conclusions}

Based on analysis of results we obtained conclusions as follows:

1. Communication positive and significant effect on online coffee purchasing decisions at the Jotey Coffee Shop.

2. Process positive and significant effect on online coffee purchasing decisions at the Jotey Coffee Shop.

3. Price has a negative and significant effect on online coffee purchasing decisions at the Jotey Coffee Shop.

4. Product positive and significant effect on online coffee purchasing decisions at the Jotey Coffee Shop.

5. Character positive and significant effect on online coffee purchasing decisions at the Jotey Coffee Shop. 
6. Risk does not have a positive and significant effect on online coffee purchasing decisions at the Jotey Coffee Shop.

\section{Suggestions}

Based on the results of this study, the suggestions that can be submitted include the following:

\section{Theoretical Suggestions}

a. Based on the results of the coefficient of determination (Adjusted R2) the variability of purchasing decisions can be explained by six variables in the model, namely communication (communication), process (process), price (price), product (product), character (character) and risk (risk) of 94.3\% while the remaining 5.7\% is influenced by other factors, so it is recommended that further research be conducted to examine other variables that influence purchasing decisions.

b. Given that the independent variables in this study are very important in influencing online purchasing decisions, it is hoped that the results of this study can be used as a consideration for further researchers to develop this research by considering other variables which are other variables outside the variables that have been included in this study. It is hoped that future researchers can conduct similar studies with a wider sample and different characteristics to validate the results of this study.

\section{Practical Advice}

a. Based on the lowest statement of variable communication on indicator 1 recommended Jotey Coffee Shop must be able to give good messages to buyers so that they are easy to understand and manage conversations on social media by placing responsive admins in every social media application his property because with good communication services, consumers will automatically feel comfortable shopping with a fast response that is presented so that it moves consumers not only to shop but also as product advocates.

b. Based on the lowest statement of variable process on indicator 3, Jotey Coffee Shop should make it easier for existing payment methods by collaborating with third parties in payment transactions.

c. Based on the lowest statement of variable price on indicator 2, Jotey Coffee Shop is recommendedshould pay more attention to pricing strategies, where the prices set can compete with other companies. As well as being able to apply discounted prices to their products in order to increase consumer interest and advance the company.

d. Based on the lowest statement of variable products on the $2 \mathrm{~d}$. Indicator suggest Jotey Coffee Shopfurther enhance the taste of contemporary coffee drinks and adapt it to consumer tastes. AlthoughJotey Coffee Shop is a coffee shop that offers coffee drinks as the main menu, but it would be better if the non-coffee drink menu offered also has a delicious taste

e. Based on the lowest statement of variable characters on indicators 1 and 4 should be The Jotey Coffee Shop can maintain and improve the current Coffee products at the Jotey Coffee Shop, such as implementing and highlighting the distinctive characteristics of the current Coffee brand at the Jotey Coffee Shop so that it looks more attractive and different from competing brands, and in the end can improve online purchasing decisions.

f. Based on the lowest statement of variable risk in indicator 1, consumers should make purchases better in assessing an item, both judging from the risks like what is obtained when making purchasing decisions without direct physical contact. Purchasing through online media has advantages, namely practical (easy,fast) and efficient (saving search costs) but also has a high risk. Based on this, when making purchases online, consumers are required to be smarter 
by paying attention to information from the products being sold and paying attention to the credibility of the seller. This is done with the aim of eliminating the risks that must be borne in online purchases.

g. Based on the lowest statement of variable buying decision In indicators 1 and 2 it is suggested that the Jotey Coffee Shop needs to add advantages, for example adding latte art to the coffee drink products offered, or even adding a home made food menu to attract consumers, besides that it also needs to add facilities that can increase consumer comfort while in Jotey's Coffee Shop. This is recommended for companies in order to achieve company targets.

\section{References}

Abdullah, Thamrin., and F. T. (2012). Manajemen Pemasaran. PT. Raja Grafindo Persada.

Aishah Arshad, Maira Zafar, Iffat Fatima, S. K. K. (2015). The Impact of Perceived Risk on Online Buying Behavior. International Journal of New Technology and Research (IJNTR), 1(8), 13-18.

Ankita Popli, S. M. (2015). Factors of Perceived Risk Affecting Online Purchase Decisions of Consumers. Pacific Business Review International, 8(2).

Asrizal Efendy Nasution. (2019). Analisis Faktor Faktor Yang Mempengaruhi Keputusan Konsumen Membeli Online. Prosiding FRIMA 2019.

Baruna Hadi Brata, Shilvana Husani, H. A. (2020). The Influence of Quality Products, Price, Promotion, and Location to Product Purchase Decision on Nitchi At PT. Jaya Swarasa Agung in Central Jakarta. Saudi Journal of Business and Management Studies. https://doi.org/10.21276/sjbms

Diana-Rose, et al. (2016). Consumers' Purchasing Decision towards Food Products of Small and Medium Enterprises. International Review of Management and Marketing.

Edward Panjaitan, Sukaria Sinulingga, R. P. W. (2019). The Effect of Marketing Mix on Consumer Purchase Decision on Bright Gas Product in Medan (Study in PT Pertamina (Persero) Marketing Operation Region I). International Journal of Research \& Review, 6(10).

Erna S.Imaningsih dan Saiful Rohman. (2018). The Model Of Product Quality, Promotion, Price, And Purchase Decisions. Jurnal Ekonomi, XXIII(2), 260271.

Evelyn Wijaya, dan W. (2019). Faktor-Faktor Yang Mempengaruhi Keputusan Pembelian Secara Online Di Shopee: Dampak Dari E-Commerce. Procuratio: Jurnal Ilmiah Manajemen, 7(2).

Gefen, D., Karahanna, E. and Straub, D.W. (2003). Trust and TAM in online shopping: an integrated model. MIS Quarterly, 27(1), 51-90.

Ghozali. (2014). Structural Equation Modeling Metode Alternatif dengan Partial Least Squares (PLS) (4th ed.). Badan Penerbit Universitas Diponegoro.

Ghozali, I. (2013). Aplikasi Analisis Multivariat dengan Program IBM SPSS (7th ed.). Penerbit Universitas Diponegoro.

Gunawan, Linawati, Pranandito, K. (2019). The Determinant Factors of E-Commerce Purchase Decision in Jakarta and Tangerang. Binus Business Review, $10(1)$.

Hardjono, B., Riyadi, S. A., \& Aris, D. (2020). The Implication of e-WoM Communication on Customer Preference and Purchase Decision of Electronic Gadgets. Jurnal Dinamika Manajemen, 11(1), 1-11. https://doi.org/10.15294/jdm.v11i1.21113

Irawan, Deny, dan Japarianto, E. (2013). Analisis Kualitas Produk Terhadap Loyalitas Melalui Kepuasan Sebagai Intervening Pada Pelanggan Restoran Poor Ke Surabaya. Jurnal Manajemen Pemasaran, 1(2).

Irawan. (2012). Manajemen Pemasaran Modern Edisi ke-2. Liberty Offset.

Istijanto. (2009). Aplikasi Praktis Riset Pemasaran. Gramedia Pustaka Utama.

Jogiyanto. (2017). Konsep Dasar Sistem Informasi. Konsep Dasar Sistem Informasi.

Katawetawaraks and Wang. (2011). Online Shopper Behavior: Influences of Online Shopping Decision. Asian Journal of Business Research, 1(2).

Kennedy, J. E. R. D. S. (2006). Marketing Communication - Taktik dan Strategi. PT Buana Ilmu Populer.

Kotler, P., \& Keller, K. (2016). Marketing Management. Pearson Pretice Hall, Inc.

Kusno, Fadli, Karyani, D. (2019). Identifikasi Faktor-Faktor Keputusan Konsumen Dalam Membeli Kopi Arabika Anglayang Karlina Di Warung Kopi Kiwari. Jurnal Agribisnis Dan Sosial Ekonomi Pertanian UNPAD, 4(2).

Lakshmi. S. (2016). Consumer Buying Behavior Towards Online Shopping. International Journal of Research - Granthaalayah, 4(8).

Lestari, Winarno, R. (2017). Analisis Faktor-faktor yang Mempengaruhi Keputusan Belanja Online: PVT Model. CITEE 2017.

Lupiyoadi, R. (2014). Manajemen Pemasaran Jasa. Salemba Empat. 
Research, Society and Development, v. 10, n. 11, e279101119543, 2021

(CC BY 4.0) | ISSN 2525-3409 | DOI: http://dx.doi.org/10.33448/rsd-v10i11.19543

Meciejewski G. (2011). The Meaning Of Perceived Risk In Purchasing Decisions Of The Polish Customers. University of Iasi, Economic Science, LVIII.

Mu LIANI. (2016). Analisis Faktor-Faktor Yang Mempengaruhi Keputusan Konsumen Kota Pontianak Dalam Melakukan Pembelian online. Jurnal Ekonomi Integra, 6(2).

Muhammad Darwin. (2020). Pengaruh Strategi Communication Dalam Marketing 4.0 Terhadap Purchase Decision Melalui Brand Advocacy Pada ECommerce Shopee. Jurnal Ilmiah MEA (Manajemen, Ekonomi, Dan Akuntansi), 4(2).

Ni Kadek Devi Aprillia Agustini. (2017). Analisis Faktor-Faktor Yang Mempengaruhi Keputusan Membeli Di Online Shop Mahasiswa Jurusan Pendidikan Ekonomi Angkatan Tahun 2012. Jurnal Pendidikan Ekonomi Undiksha, 9(1).

Parmana, Idqan Fahmi, and D. R. N. (2019). The Influence Of Marketing Mix Factors In Purchasing Decision For Wooden Furniture Case Of Furnimart Bogor. Indonesian Journal of Business and Entrepreneurship, 5(1).

Philip Kotler, G. A. (2010). Principles of marketing. Pearson Prentice Hall.

Ryan Kusumah. (2015). Analyze The Effect Of Trust, Price, Quality And Perceived Risk Toward Consumer Purchase Behavior In Online Shops Instagram. Jurnal Berkala Ilmiah Efisiensi, 15(5).

Samani. (2011). Pendidikan Karakter: Konsep dan Model. Remaja Rosdakarya.

Sangadji, E.M., dan S. (2013). Prilaku Konsumen: Pendekatan Praktis Disertai: Himpunan Jurnal Penelitian. Penerbit Andi.

Sheikh Qazzafi. (2019). Consumer Buying Decision Process Toward Products. International Journal of Scientific Research and Engineering Development, 2(5).

Sugiyono. (2014). Metode Penelitian Pendidikan Pendekatan Kuantitatif, kualitatif, dan R\&D. Alfabeta.

Sulaksana, U. (2007). Integrated Marketing Communications. Pustaka Pelajar.

Turban, Efraim, et al. (2004). Electronic Commerce a Managerial Perspective. Pearson.

Wahono, B. (2020). Penentu Keputusan Pembelian Online: Pelajaran Empiris dari Olx.co.id. Literatus Literature For Social Impact And Cultural Studies, 2(2), 96-104.

Wardoyo, W., \& Andini, I. (2017). Faktor-Faktor Yang Berpengaruh Terhadap Keputusan Pembelian Secara Online Pada Mahasiswa Universitas Gunadarma. Jurnal Manajemen Dayasaing, 19(1), 12. https://doi.org/10.23917/dayasaing.v19i1.5101

Widya Rambi. (2015). The Influence Of Consumer Behavior On Purchase Decision Xiaomi Cellphone In Manado. Jurnal EMBA, 3(2). 